\title{
PRUSKIE WSIE LINIOWE W OKOLICACH LODZI I ICH MIESZKAŃCY W POCZĄTKACH XIX WIEKU
}

\begin{abstract}
Zarys treści: Odszukane w zbiorach Gabinetu Rycin Biblioteki Uniwersytetu Warszawskiego rękopiśmienne plany wsi (,kolonii”) założonych w latach 1799-1802 przez władze pruskie w okolicach Łodzi, stały się zachętą do przybliżenia ich historii. Na podstawie źródeł archiwalnych i literatury zrekonstruowano trudne początki gospodarowania sprowadzonych do nich osadników z głębi Niemiec. Scharakteryzowano przesłanki i omówiono czynniki pozwalające omawianym wsiom zachować układ przestrzenny oraz odrębność kulturową mieszkańców.
\end{abstract}

Słowa kluczowe: osadnictwo, wsie liniowe, Prusy Południowe, migracje, okręg łódzki, Niemcy.

\section{Wprowadzenie}

Inspiracją do podjęcia tematu było odszukanie w zbiorach Gabinetu Rycin Biblioteki Uniwersytetu Warszawskiego rękopiśmiennych planów wsi (,kolonii”) założonych w latach 1799-1802 przez władze pruskie w okolicach Łodzi ${ }^{1}$. To jedyne, znane materiały kartograficzne ilustrujące proces zakładania na terenie Prus Południowych wsi zasiedlanych chłopami sprowadzanymi z głębi Rzeszy $^{2}$. Plany poszczególnych miejscowości wykonali pruscy geometrzy, prawdopodobnie zatrudnieni w departamencie kamery warszawskiej: Kramm, Kunzel, Friedrich Wilhelm Sievert. Skopiowane zostały przez Zirkela, który ponadto był autorem mapy obejmującej wycinek terenu mieszczącego się

\footnotetext{
${ }^{1}$ Biblioteka Uniwersytetu Warszawskiego, Gabinet Rycin, sygn. Inw. GR 300 oraz Inw. GR 299: Generelle Situations Karte Eines Theils des Königlichen Hochloblichen Warschauer Kammer Departements, worauf die fünf neu etablierte Colonien ihrer Laage und Grösße nach eingetragen sind. Aufgenommen und gezeichnet durch Zirkel [ca. 1802].

${ }^{2}$ Część z nich opublikował po raz pierwszy K.P. Woźniak (2013, s. 342-347).
} 
w trójkącie: Głowno-Będków-Bałdrzychów ${ }^{3}$. Było to pogranicze departamentu warszawskiego i kaliskiego. Zarówno plany, jak i mapa są orientowane i skalowane $\mathrm{w}$ łokciach reńskich. Obie karty sygnowane są owalną pieczątką „W:H:Minter”, co dowodzi, że były częścią zbioru rycin i planów architektonicznych (tzw. Teki Minterowskie), zgromadzonego przez Wilhelma Henryka Mintera (1777-1832), inżyniera-architekta, pułkownika korpusu inżynierów armii Księstwa Warszawskiego i wojsk Królestwa Polskiego (Szulc 1989, s. 390-391).

Zagarnięcie przez Prusy rozległych połaci ziem środkowej Polski w 1793 roku i utworzenie nowej prowincji, Prus Południowych, oznaczało istotne zmiany w stosunkach gospodarczych. Nowy nabytek zaczęto traktować jako swego rodzaju pomost łączący Śląsk z Prusami Wschodnimi i za pożądane uznano zwiększenie liczby Niemców na terenach nowo wcielonych do państwa, ustępujących pod tym względem sąsiednim prowincjom. Ekspansji politycznej i terytorialnej państwa Hohenzollernów towarzyszyło przyjęcie i upowszechnienie odmiany doktryny merkantylistycznej, zwanej kameralizmem. Kameralizm wyrósł na gruncie stosunkowo zacofanej struktury gospodarczej, społecznej i politycznej Niemiec, stając się narzędziem zmian. Doktryna zakładała pełne wykorzystanie zasobów ludzkich i zdolności produkcyjnych w celu zwiększenia dochodów władcy, skupiając się głównie na sprawach panującego, gdyż pomyślność władcy miała być równoznaczna z pomyślnością kraju. Kameralistyka pruska wychodziła też z założenia, że pomyślność i siła państwa jest funkcją liczebności jego poddanych. Od czasów Fryderyka II „Peuplierungspolitik” (polityka ludnościowa) stała się praktyką państwową, zgodnie z dewizą, którą wpoił mu ojciec Fryderyk Wilhelm I: „Menschen halte vor den größten Reichtum” (Ludzi uważam za największe bogactwo) (Kuhn 1971, s. 183). Współbrzmiało z nią dążenie do stworzenia silnej i licznej armii, gdyż jej rozbudowa i zaspokajanie jej potrzeb wymagały wzrostu ludności i rozwoju rzemiosł (Górski 1985, s. 82). W odniesieniu do polityki osadniczej realizowanej przez Prusaków na zagarniętych w wyniku rozbiorów ziemiach I Rzeczypospolitej, polska literatura przedmiotu posługuje się terminem „kolonizacja fryderycjańska” (rzadziej: „osadnictwo fryderycjańskie"). Wydaje się to uproszczeniem. Ogromny rozmach, z jakim zasiedlano Górny Śląsk oraz Obwód Nadnotecki, był przede wszystkim efektem woli samego monarchy, Fryderyka II. Jego następca na tronie pruskim, Fryderyk Wilhelm II, nie przejawiał większego zainteresowania kontynuacją dzieła stryja. Dopiero Fryderyk Wilhelm III powrócił do polityki kolonizacyjnej we wschodnich prowincjach państwa, ale rzeczywistymi jej wykonawcami byli ministrowie króla. Można więc mówić nie o kolonizacji fryderycjańskiej, lecz raczej o kontynuacji tradycji tej polityki. Takie stanowisko prezentuje

${ }^{3} \mathrm{O}$ autorach brak bliższych informacji, poza potwierdzeniem zatrudnienia F.H. Sieverta w biurach inspekcji budowlanej w Warszawie (GStaPK, II HA, sygn. 142, k. 121, 127; Czochański, Kowalski, 2014, s. 249-253). 
historiografia niemiecka (Volker 1927, s. 18; Heike 1953, s. 28; Kuhn 1971, s. 193). Komentarza jednak wymaga upowszechniony w niej termin „kolonizacja”, obarczony dawną tradycją postrzegania niemieckiego chłopa jako „pioniera” postępu, lepszych sposobów gospodarowania. Określenie „kolonista” wywodzi się z języka źródeł współczesnych osadnictwu, zarówno z dokumentów polskiej administracji schyłku XVIII wieku, jak i z języka potocznego i odnosi się do chłopów osadzanych na gruntach jako czynszownicy. Koloniami nazywano zamieszkane przez nich wsie. Ta ostatnia nazwa ugruntowała się w czasach pruskich, ponieważ wszystkie zakładane wówczas osady miały w oficjalnej nomenklaturze status „königliche Kolonien”. Autor opowiada się za stosowaniem terminów „osadnictwo”, „osadnik” jako lepiej oddających rzeczywistość historyczną, co nie wyklucza posługiwania się określeniem kolonista, gdy wymaga tego potoczystość narracji.

Mimo że już 17 listopada 1793 roku Fryderyk Wilhelm II wydał ministrowi Prus Południowych, Otto von Vossowi, dyrektywę dotyczącą polityki kolonizacyjnej na podległym mu terytorium, to żadnych działań nie podjęto. Nie rozpoczął ich także następca Vossa, Karl Georg von Hoym. Prowadzona przez niego gospodarka krytykowana była przez rząd pruski. Wątpliwości budziło zwłaszcza rozdawnictwo dóbr, które trafiły w ręce ludzi bez zasług, intrygantów czy wręcz złodziei (Sokołowski 1904, s. 144; Wąsicki 1955, s. 693-703). Sytuacja zmieniła się w 1797 roku po objęciu rządów przez Fryderyka Wilhelma III, który odwołał Hoyma i przywrócił O. Vossa. Podjęte w ostatnich latach XVIII wieku próby zaludniania Prus Południowych drogą kolonizacji „wewnętrznej”, to jest osadnikami pochodzącymi z Prus Zachodnich czy Brandenburgii, nie powiodły się. Mrzonką okazała się też inicjatywa niejakiego Johanna Friedricha Eyserle, deklarującego sprowadzenie 100 rodzin niemieckich chłopów z Łotwy (Kossmann 1942, s. 182). Fiasko tych usiłowań zbiegło się z wyraźnym sprzeciwem władcy Prus wobec wyludniania „starych” prowincji pruskich, jako jeszcze stosunkowo mało zaludnionych. Obawiano się, że duże przesunięcia ludności mogłyby się odbić na ich położeniu gospodarczym. Władze pruskie zwróciły więc uwagę na małe i przeludnione kraje południa Rzeszy: Wirtembergię i Badenię. Powiększającą się z roku na rok emigrację z tych terenów do Ameryki zdecydowano skierować do Prus Południowych i Nowowschodnich (Beer 1999, s. 17).

W 1798 roku zaczęto przygotowywać akcję zaludniania wschodnich prowincji państwa osadnikami rekrutowanymi w Wirtembergii i Badenii, ale także pochodzącymi z Palatynatu, Alzacji, północnych krańców Hesji. Były to tereny historycznej Szwabii, toteż imigrantów stamtąd, zwłaszcza Wirtemberczyków, nazywano Szwabami. Ogromne zasługi dla rozwinięcia akcji osadniczej położył nieznany dziś z imienia, kapitan von Nothardt. Wyposażony w pełnomocnictwa rządu pruskiego, zorganizował ogromny aparat werbunkowy, którego trzon stanowiło „Reichs-Kolonisten-Annahme-Büreau” w Öhringen k. Heilbronn w Wirtembergii. Udało mu się też przekonać Fryderyka Wilhelma III, że nastał właśnie bardzo dobry czas na agitację i pozyskiwanie chętnych, ponieważ 
w południowych Niemczech i w Nadrenii, z powodu panującego tam kryzysu gospodarczego, wielu chłopów i rzemieślników decydowało się emigrować (Simsch 1983, s. 217). Ówczesne relacje w bardzo sugestywny sposób opisywały „gorączkę emigracyjną”. „Wszędzie tam po miastach, miasteczkach i wsiach roiło się od emisariuszów i agentów, drogi dniem i nocą pełne były taborów, wózków i taczek (z dziećmi) przenoszących się rodzin, gościńce rozlegały się rozhoworem idących na zwiady lub powracających - a urzędnicy administracyjni obarczeni byli kłopotliwymi sprawami emigracyjnymi” (Zimmermann 1915, s. 32). Objęcie tego przedsięwzięcia patronatem króla musiało przyczynić się do powodzenia. Początkowo planowano, że wszyscy imigrujący chłopi otrzymają w miejscach osiedlenia gospodarstwa o powierzchni 60 morgów. Zapowiedź taka okazała się szczególnie atrakcyjna dla chłopów małorolnych i dla tych synów chłopskich, którzy nie mogli liczyć na nadziały z ojcowizny. Oni właśnie stanowili pierwszą grupę imigrantów szukających na wschodnich rubieżach Prus poprawy swego losu. Tymczasem władzom pruskim zależało na pozyskaniu do przesiedlenia chłopów zamożnych, którzy byliby w stanie samodzielnie gospodarować od razu po przybyciu w nowe miejsca. Ta rozbieżność oczekiwań sprawiła, że władze berlińskie kilkakrotnie dokonywały zmian przepisów określających warunki osiedlania się w Prusach Południowych.

W styczniu 1803 roku wprowadzono podział kolonistów na VI klas, zależnie od kwoty gotówki, którą dysponowali. Suma ta decydowała o zakresie wsparcia udzielanego przez państwo. Niezależnie od tego, wszystkich kolonistów obowiązywały jednakowe regulacje prawne (AGAD, RSiRMKsW, II 215). Zwracało uwagę umieszczenie już w art. 1 gwarancji zwolnienia osadnika i jego synów ze służby wojskowej. Prawodawca miał świadomość, że wobec perspektywy długoletniej służby w armii pruskiej przepis ten jest bardzo atrakcyjny dla potencjalnych kolonistów i może przesądzić o podjęciu decyzji przesiedlenia się do nowej, wschodniej prowincji państwa. Osadnicy otrzymywali grunty jako dzierżawę wieczysto-czynszową, z których opłacać mieli czynsz po upływie lat wolnych. Wolnizna wynosiła od trzech do sześciu lat i zależała od rodzaju gruntu i zakresu prac, które należało wykonać przy jego zagospodarowaniu. Wysokość czynszu miała się zmieniać wraz z ceną zboża. W przypadku zalegania z opłatą, rząd zastrzegał sobie prawo odebrania gruntu. W czasie trwania wolnizny osadnik zwolniony był od wszelkich podatków. Bez zezwolenia rządu nie wolno było osady dzielić ani obciążać długiem. Przy sprzedaży gruntów, poza zbyciem na rzecz dzieci, osadnik zobowiązany był zapłacić skarbowi laudemium w wysokości połowy rocznego czynszu. W osadach, w których kosztem rządu wzniesiono zabudowania, kolonista musiał ubezpieczyć je w towarzystwie ogniowym i dbać o ich dobry stan. Gdyby zabudowania zgorzały, osadnik miał wystawić nowe na własny koszt. Przewidywano też inne obowiązki kolonisty: opłacanie podatku dymowego (pruski odpowiednik staropolskiego podymnego), dostarczanie furażu i podwód (Heike 1979, s. 8-10). Koloniści zaliczeni do I klasy (posiadający od 30 do 500 zł reńskich), otrzymywali nadziały ziemi o powierzchni 
czterech morgów, wyjątkowo sześciu morgów. Zobowiązani byli utrzymywać budynki wzniesione na koszt rządu. Przysługiwało im od trzech do sześciu lat wolnych i wynagrodzenie za karczunek gruntu. Otrzymywali też zwrot kosztów podróży w wysokości 2 dobrych groszy za 1 milę od osoby. Własnością kolonisty stawały się sprzęty gospodarskie: sierp, kosa, grabie, widły, cepy, siekacz, szufla, rydel, siekiera, cieślica, taczka, międlica, „kółko” (kołowrotek) do przędzenia. Zestaw narzędzi pozwalał nie tylko na wykonywanie ręcznych prac polowych, ale także podstawowych robót drwalsko-ciesielskich. Międlica i kołowrotek przędzalniczy wskazują na przewidywane przez władze podjęcie przez najmniej zamożnych kolonistów zajęć dodatkowych przy obróbce i przędzeniu włókien (lnu lub konopi). Osadnicy klasy I otrzymywali od rządu inwentarz żywy: dwie krowy, jedną świnię, cztery gęsi, cztery kury i koguta (AGAD, RSiRMKsW, II 215, s. 248). Koloniści II klasy, legitymujący się majątkiem wynoszącym od 500 do 1000 zł reńskich, kierowani byli do opuszczonych osad chłopskich o powierzchni od 15 do 40 morgów. Otrzymywali zwrot kosztów podróży na takich samych zasadach jak osadnicy klasy I, byli też wynagradzani za karczunek. Ponadto przydzielano im ,sprzęty gospodarskie i na załogę inwentarzy w miarę wielkości danej osady" (AGAD, RSiRMKsW, II 215, s. 249). Osadnicy zaliczeni do klasy III (1000- 2000 zł reńskich), otrzymywali trzy łany magdeburskie gruntu oraz przydział drewna na dom i budynki gospodarcze. Udzielano im pożyczki w wysokości 600 talarów na okres od 5 do 15 lat, od której nie płacili prowizji oraz kwotę 200 talarów jako podarunek od rządu. Ta grupa osadników nie była wyposażana ani w inwentarz żywy, ani w narzędzia. Podobne warunki gwarantowano kolonistom zaliczonym do klasy IV (20003000 zł reńskich). Jedyną różnicą w stosunku do osadników klasy III był większy nadział gruntu, obejmujący cztery łany. Koloniści klasy V (3000-4000 zł reńskich) otrzymywali pięć łanów gruntu oraz pożyczkę w wysokości 1400 talarów, którą obowiązani byli spłacić podczas lat wolnych. $\mathrm{Z}$ kolei koloniści zaliczeni do klasy VI (4000-5000 zł reńskich), korzystający z takich samych dobrodziejstw jak klasa V, obejmowali sześć łanów gruntu. Nie ma potwierdzenia źródłowego dla tworzenia gospodarstw pięcio- i sześciołanowych, z czego wynika, że tak zamożni osadnicy nie przybywali na teren departamentu kamery warszawskiej.

Na terenie Prus Południowych władze dysponowały gruntami w domenach państwowych, które utworzono z sekularyzowanych dóbr kościelnych i starostw skonfiskowanych za udział ich dzierżawców w powstaniu kościuszkowskim (Gavlitta 2009, s. 26-27). Areał ten nie był jednak wystarczająco duży. Podstawowe znaczenie dla przeprowadzenia szerzej zakrojonej akcji osadniczej w Prusach Południowych miała decyzja o realizowaniu jej na obszarach leśnych (Urkunden... 1961, s. 489-496). Administracja pruska nie miała dobrego rozeznania co do wyboru miejsc, w których mogłyby być zakładane nowe osady. Starano się przede wszystkim nie wchodzić w konflikt z urzędami leśnymi. Lasy traktowane były w monarchii Hohenzollernów jako dobro o znacznej wartości, 
toteż już od końca XVIII wieku zaczęto prowadzić w nich racjonalną gospodarkę. Do wykorzystania rolniczego przeznaczano więc tylko tzw. odpadki leśne lub lasy rosnące na terenach podmokłych, trudno dostępnych (Kossmann 1942, s. 174). Do takich obszarów należały ekonomie Łaznów i Tkaczew w sekularyzowanych dobrach biskupstwa włocławskiego. Był to teren pod każdym względem mało atrakcyjny. Brakowało dobrych dróg, niewielkie i niespławne rzeczki nie pozwalały wykorzystać jedynego praktycznie bogactwa - drewna. Osadnikom obiecywano grunty na otwartym terenie, tymczasem osiedlani byli w lasach. W informacjach zachęcających do przesiedlenia się do Prus Południowych wabiono chętnych sformułowaniem, że zostaną wynagrodzeni za karczunek, jeżeli [podkreślenie K.P.W.] otrzymają grunty zalesione. Administracja pruska wywiązywała się z finansowych zobowiązań, ale osadnicy byli niemal bez wyjątku lokowani na terenach zalesionych. Rodziło to problemy i budziło niezadowolenie przybyszów.

Obok polskich wsi pańszczyźnianych władze pruskie zastały w nowej prowincji wiele osad olęderskich założonych w latach 1782-1797 (Figlus 2014). Opinia lokalnych urzędników o ich mieszkańcach nie była najlepsza. Olędrzy przyzwyczajeni już do własnych siedlisk nie godzili się na prostowanie ich granic, wytyczanie nowych dróg (Kossmann 1942, s. 178-179). Chętnie natomiast wynajmowali się do karczunku drzew w osadach przybyszów z Wirtembergii, którzy nie mieli żadnego doświadczenia w takiej pracy. „Die Württemberger, welche nicht Gut mit dem Roden umzugehen wissen, Hauländer die mit dergleichen Arbeiten bekannt sind, und ihre eigene Ländereien schon urbar gemacht haben, für Geld zum roden dingen (...)” (AGAD, GDDPP, I 488).

Zorganizowany napływ niemieckich chłopów do Prus Południowych rozpoczął się w 1800 roku. Pierwszą dużą kolonią szwabską w Prusach Południowych, przy zakładaniu której władze pruskie po raz pierwszy praktycznie realizowały swoje teoretyczne plany kolonizacji, był Grömbach (Łaznowska Wola) (Heike 1979, s. 40, rys. 1). O nazwach nowo zakładanych kolonii decydowali ich mieszkańcy. $Z$ reguły wybierali nazwy, które były odpowiednikami nazw ich ojczystych wsi. Leżące w trójkącie Łęczyca-Lask-Łódź szwabskie kolonie: Grömbach, Neu-Sulzfeld (Nowosolna), Königsbach (Bukowiec), Grünberg (Zielona Góra), Effingshausen (Starowa Góra), Neu-Württemberg (Tkaczewska Góra), Hochweiler (Markówka), Schöneich (Krasnodęby) wzięły swoje nazwy od miejscowości leżących między Stuttgartem, Heilbronn i Karlsruhe. Spolszczenia niemieckich nazw, najczęściej poprzez dosłowne thumaczenie, dokonano w 1820 roku na mocy postanowienia namiestnika Królestwa Polskiego (Dziennik Urzędowy... 1820).

W maju 1800 roku 10 rodzin szwabskich wyruszyło z leżącego na północnych krańcach Schwarzwaldu Grömbach, rozpoczynając podróż do Prus Południowych. Na pięciu wozach zaprzężonych w osiem koni przebyli 152 mile (około $850 \mathrm{~km}$ ). Większość imigrantów stanowili rolnicy, ale byli wśród nich 
także rzemieślnicy, łączący swoją profesję z pracą na roli ${ }^{4}$. Kamera warszawska stwierdziła, że przybysze, poza niewielka ilością gotówki, niemal niczego nie posiadają (Schmit 1942, s. 122). Wyposażeni w narzędzia do karczunku skierowani zostali w lasy pod Zgierzem. Już po dwóch miesiącach alarmowali władze, że nawet 20 lat nie wystarczy, aby ziemię porośniętą gęstym lasem zamienić w pola uprawne.

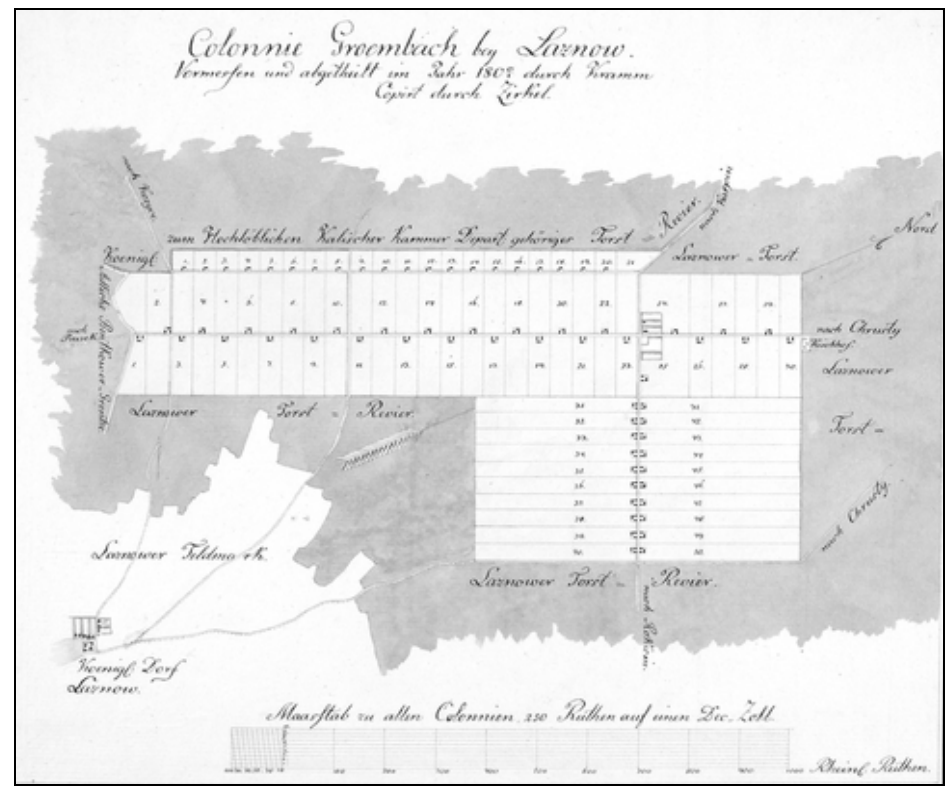

Rys. 1. Plan kolonii Groembach/Łaznowska Wola (1801)

Źródło: Biblioteka Uniwersytetu Warszawskiego, Gabinet Rycin, sygn. GR 300

Wkrótce przeniesiono ich w lasy ekonomii Łaznów, gdzie organizowano kolonię złożoną z 30 gospodarstw. Zimę z 1800 na 1801 roku osadnicy przetrwali w półziemiankach, natomiast wiosną zaczęto wznosić pierwsze budynki. Z braku gliny, za zgodą kamery warszawskiej, odstąpiono od konstrukcji szachulcowej (ryglowej), budując wyłącznie z drewna, którego było pod dostatkiem. Wznoszenie znormalizowanych budynków w osadzie powierzono przedsiębiorcy von Prussakowi. Budynek mieszkalny miał wymiary 40 na 27 stóp reńskich $\left(106,3 \mathrm{~m}^{2}\right)$, stajnia 36 na 16 stóp $\left(56,75 \mathrm{~m}^{2}\right)$, a stodoła 48 na 34 stopy $\left(160,7 \mathrm{~m}^{2}\right)($ Schmit 1942, s. 137; Ihnatowicz 1967, s. 34). Zalecono także kopanie jednej studni dla dwóch sąsiadujących ze sobą gospodarstw. Ogłoszona

${ }^{4}$ To charakterystyczna cecha rzemiosła niemieckiego na przełomie XIX i XX wieku, zlokalizowanego głównie na wsi i połączonego z uprawą roli (Schmoller 1870, s. 241). Do Łaznowskiej Woli przyjechali: garbarz, cieśla, rymarz, płóciennik, dwóch szewców, czterech kołodziei, karczmarz (AGAD, CWW, sygn. 1238, s. 33-35). 
w 1801 roku zmiana warunków osiedlania zmusiła kamerę warszawską do wydzielenia dodatkowych 20 parcel dla zagrodników (Häuslerstellen) i 21 parcel dla chałupników (Büdnerstellen). Wieś zmieniła wówczas swój kształt. Równolegle do linii drogi, przy której skupiały się 60 morgowe gospodarstwa, wytyczona została droga $\mathrm{z}$ ulokowanymi po jednej jej stronie zabudowaniami chałupników. Natomiast w przedłużeniu jednej z trzech dróg prostopadłych do głównej wymierzono parcele zagrodnicze. Wówczas też wydzielono 6-morgową parcelę dla pastora, jedną morgę pod kościół ${ }^{5}$, cztery morgi pod szkołę, trzy morgi pod kuźnię, cztery morgi pod wspólny dla wsi sad, dwie morgi pod cmentarz (AGAD, CWW, 1240, s. 160-164). Takie rozplanowanie wsi jest widoczne na planie Kramma (BUW GR, Inw. GR 300). Zwraca też uwagę rozmieszczenie budynków na działce domowej. Dom mieszkalny i stajnia były posadowione naprzeciw siebie, szczytami do drogi, natomiast stodoła, równoległa do drogi, zajmowała miejsce w prawym kącie czworokątnego podwórza. Ten układ powtarza się na pozostałych planach z lat 1799-1802. Sądząc z XX-wiecznych fotografii wsi Borowa, takie usytuowanie budynków utrwaliło się (Effenberger 1999, s. 5). Trwałe i pożyteczne okazało się także zamierzone przez władze pruskie zróżnicowanie majątkowe i zawodowe mieszkańców kolonii. W 1826 roku w Łaznowskiej Woli we wsi mieszkały 72 rodziny, z których 48 utrzymywało się tylko z uprawy roli. Pozostali to: 13 wyrobników, czterech kołodziei, dwóch szewców, garbarz, cieśla, rymarz, płóciennik, karczmarz (AGAD, CWW, 1238, s. 32-35).

W tym samym czasie co Laznowska Wola została założona kolonia Friedrichshagen (Augustów), której obszar na skraju „królewskiego łódzkiego rewiru leśnego" (Königlicher Lodzer Forst-Revier) wymierzył na przełomie lat 18001801 geometra Sievert (BUW GR, Inw. GR 300) (rys. 2). Od zachodu osada graniczyła z folwarkiem Zarzew i dobrami Chojny, a od południa z gruntami Wiskitna należącego już do kamery departamentu kaliskiego. Pierwsi przybysze pojawili się w Augustowie wiosną 1801 roku, ale na miejscu pozostało tylko siedem rodzin mogących wylegitymować się kapitałem pozwalającym objąć gospodarstwa 60-morgowe. Rok później pojawili się kolejni chłopi z Wirtembergii. W czasach Księstwa Warszawskiego dokonano zmiany nazwy wsi, tworząc ją od imienia ówczesnego władcy Fryderyka Augusta. W 1828 roku Augustów liczył 12 gospodarstw. Dwa z nich obejmowały po 120 morgów, jedno 90 morgów, sześć po 60 morgów oraz jedno 54 morgi, jedno 24 morgi i jedno 10 morgów (Heike 1979, s. 101). Plan Sieverta sporządzony na przełomie lat 1800 i 1801 nie uwzględniał tego podziału, natomiast widoczny jest na nim grunt przeznaczony na cmentarz, wydzielony z działki nr 15 (BUW GR, Inw. GR 300).

5 „Dom modlitwy kosztem rządu pruskiego wystawiony został” (AGAD, CWW, sygn. 1240 , s. 160). 
Jeszcze mniejsza, założona w 1800 roku, była osada (,neu etablierte Colonie") Schöneich (Krasnodęby Stare) pod Parzęczewem, w lasach należących do ekonomii Zdziechów (rys. 3). Pierwsi koloniści przybyli do Krasnodębów wiosną 1800 roku, ale po dwóch miesiącach porzucili przydzielone im działki, gdyż karczunek przekraczał ich siły. Latem 1801 roku było już dwóch osadników z Wirtembergii oraz pięciu z Księstwa Baden-Durlach, każdy na 60-morgowym gospodarstwie (Kossmann 1942, s. 194). O tej małej, leżącej w głębi dużego kompleksu leśnego kolonii, nie natrafiono na źródła, które przybliżałyby jej dzieje. Błędną informację zawiera tzw. mapa kwatermistrzostwa, na której wieś występuje pod nazwą „Krasnodębie Hol.” jako rzekoma osada olęderska.

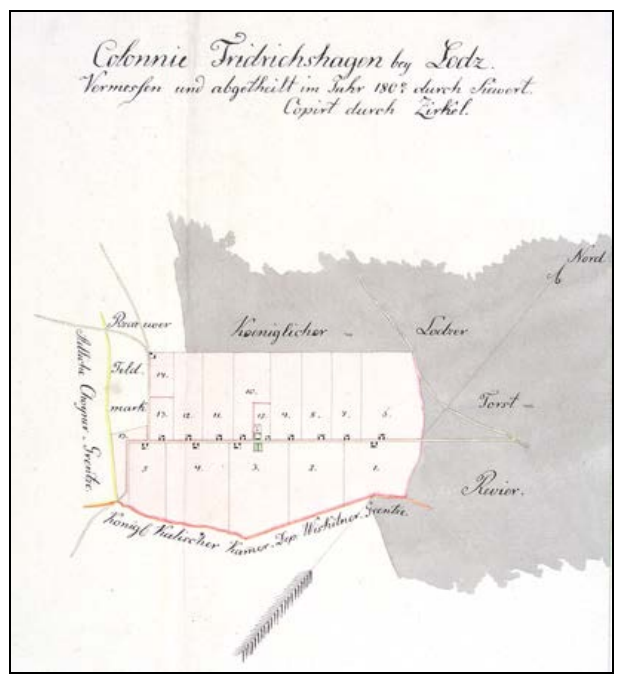

Rys. 2. Plan kolonii Friedrichshagen/ Augustów (1801)

Źródło: Biblioteka Uniwersytetu Warszawskiego, Gabinet Rycin, sygn. GR 300

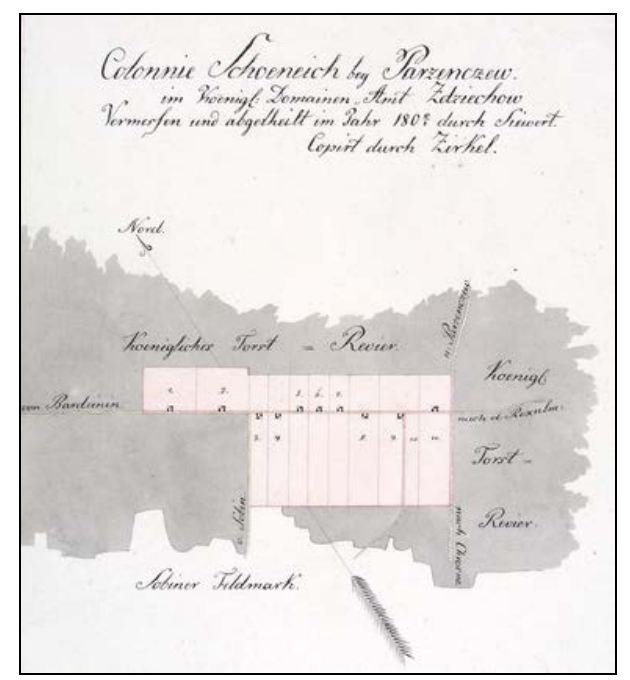

Rys. 3. Plan kolonii Schoeneich/ Krasnodęby (1801)

Źródło: Biblioteka Uniwersytetu Warszawskiego, Gabinet Rycin, sygn. GR 300

Dzieje Nowosolnej (Neu-Sulzfeld, Sulzfeld) i jej mieszkańców są stosunkowo dobrze udokumentowane. Przyciągała uwagę badaczy jako najludniejsza i najzamożniejsza wieś szwabska na ziemiach polskich, w unikatowy sposób rozplanowana, a przede wszystkim ze względu na rolę, jaką odegrała w działalności braci morawskich (herrnhutów) (Steinberg 1924; Hochgeladen 1937; Kossmann 1938; Heike 1979, s. 61-87; Karczyńska 2009, s. 39-53). Swoje powstanie zawdzięczała wytrwałości pochodzącego z Sulzfeld (Kraichgau) na północy Badenii Bernharda Zimmermanna. W 1800 roku jako jeden z pierwszych Szwabów osobiście zapoznał się z warunkami panującymi w Prusach Południowych i postanowił osiedlić się w lasach ekonomii Łaznów. Wiosną 1801 roku zorganizował grupę 60 rodzin (z Wirtembergii, Badenii, Alzacji 
i Palatynatu), która drogą przez Berlin, gdzie wypłacono im „milowe” (Meilengelder), ruszyła na wschód. Wśród imigrantów przeważali małorolni chłopi, którym władze kamery warszawskiej odmówiły przydziału dużych gospodarstw, proponując niewielkie parcele chałupnicze na terenach podległych kamerze kaliskiej. Zimmermann interweniował $\mathrm{w}$ tej sprawie w Berlinie, uzyskując audiencję u króla i zapewnienie, że wszyscy przybyli z nim do Nowosolnej otrzymają w niej grunty.

Przy rozplanowywaniu terenu pod kolonię Nowosolna okazało się, że sięga ona po wsie Wiączyń Dolny i Wiączyń Górny, obie zamieszkane przez polskich chłopów świadczących pańszczyznę na rzecz folwarku wiączyńskiego, graniczącego z lasami państwowymi (rys. 4). Zdecydowano wówczas przenieść 15 chłopów z obu wsi do nowo założonej na wykarczowanych kosztem rządu pruskiego gruntach leśnych wsi Nowy Wiączyń. Równocześnie postanowiono, że „die Translocierung der Bauern so geschehen müsse, da $\beta$ sie nicht über Druck klagen können und sich nicht gegen die Ausländer zu sehr zurückgesetzt fühlen” (Heike 1979, s. 88). W praktyce oznaczało to, że przesiedleni polscy chłopi osadzeni zostali jako wieczyści czynszownicy, otrzymując takie samo wsparcie materialne jak okoliczni osadnicy niemieccy. Był to jedyny w Prusach Południowych przypadek, w którym zakładanie nowej kolonii wiązało się z koniecznością zmian granic starszych siedlisk i translokacją ich mieszkańców. Zachowany plan Nowosolnej, sporządzony przez Kunzela w 1802 roku (BUW GR, Inw. GR 300), ukazuje oryginalny, gwiaździsty kształt osady, w którym można doszukiwać się analogii do układu przestrzennego Karlsruhe, miasta znanego wielu mieszkańcom północnego Schwarzwaldu, choćby z racji odbywania służby wojskowej w tamtejszym garnizonie ${ }^{6}$. Północnowschodnia granica osady, stykająca się tam z lasami wiączyńskimi, określona jest jako sporna (,aber strittig”). Brak jest jednak w źródłach informacji o przyczynie i rodzaju tego sporu. Powierzchnia Nowosolnej obejmowała 6371 morgów, w tym: 5499 morgów lasu, 631 morgów ziemi nadającej się pod uprawę żyta i owsa, 5 morgów łąk średniej jakości, 41 morgów złych łąk, 50 morgów pokrytych zaroślami i 146 morgów nieużytków (Heike 1979, s. 66). Do użytkowania rolniczego nadawało się zatem 12\% powierzchni. Pozostałe grunty musiały być karczowane i zagospodarowywane. W 1802 roku kamera warszawska informowała władze berlińskie, że „die Colonisten zwar sehr schwere Rodung haben, aber solche mit sehr viel Fleiss betreiben". Koloniści posiadający 2-4 łany ziemi otrzymywali tzw. dary z łaski (Gnadengeschenk), dzięki którym sami mogli budować domy. Gospodarującym na 30 morgach i chałupnikom budynki wznoszono na koszt rządu. Budynki wznoszono w konstrukcji szachulcowej i kryto je strzechą słomianą. Tę praktykę

${ }^{6}$ Miejscowością o identycznym założeniu i bez wątpienia wzorowaną na planie Karlsruhe jest wieś Pokój (historyczna nazwa: Carlsruhe) w województwie opolskim, w powiecie namysłowskim (http://carlsruhe.jimdo.com/carlsruhe-pok\%C3\%B3j/(dostęp: 03.06.2015). 
trudno zrozumieć, ponieważ okolica dostarczała dość drewna na pokrycie dachów gontem lub dranicami. W 1805 roku spośród 212 łanów, 71 było już wykarczowanych. Liczne prośby kolonistów o wsparcie finansowe w ich ciężkiej pracy były jednak odrzucane. Dopiero po odwiedzinach kolonii przez ministra O. Vossa w czerwcu 1805 roku wieś otrzymała wsparcie w wysokości 3200 talarów. W 1803 roku wystawiono budynek szkoły. Nieco dłużej trwała budowa kościoła, oddanego do użytku w 1805 roku, jako centrum parafii obejmującej Nowosolną i okoliczne osady zamieszkane przez ewangelików.

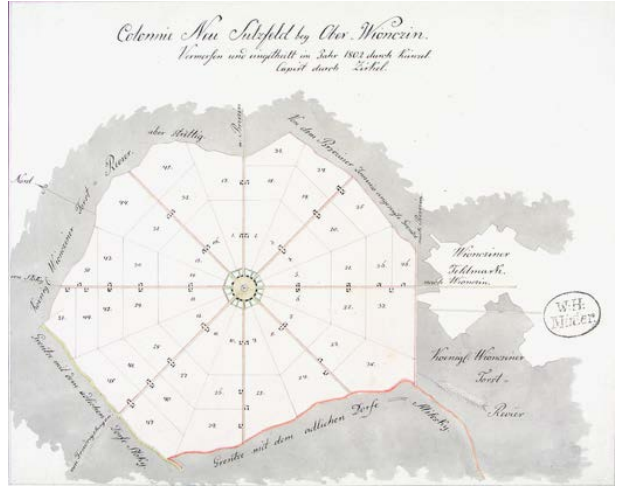

Rys. 4. Plan kolonii Neu Sulzfeld/ Nowosolna (1802)

Źródło: Biblioteka Uniwersytetu Warszawskiego, Gabinet Rycin, sygn. GR 300

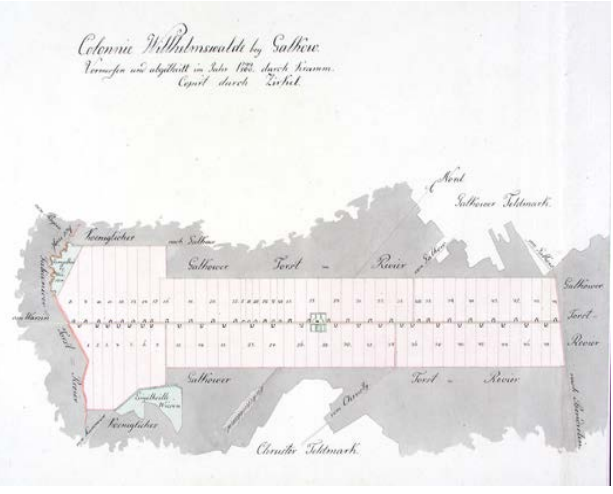

Rys. 5. Plan kolonii Wilhelmswalde/ Borowa (1800)

Źródło: Biblioteka Uniwersytetu Warszawskiego, Gabinet Rycin, sygn. GR 300

Chociaż władze pruskie starały się przestrzegać zasady werbowania osadników tylko z południowo-zachodnich terenów Rzeszy, to przecież nie były w stanie zapobiec przesiedlaniu się chłopów poszukujących ziemi z innych prowincji pruskich. Przykładem jest założona w 1799 roku kolonia Wilhelmswalde (Borowa) k. Łodzi, której plan, jako klasycznej wsi liniowej, sporządzony został najwcześniej (BUW GR, Inw. GR 300, rys. 5). Szalejący wiosną 1799 roku huragan spustoszył duży obszar lasu na południe od Gałkowa. Wykorzystano tę okoliczność do założenia w miejscu wiatrołomu kolonii nazwanej Wilhelmswalde. Nazwa upamiętniać miała króla Fryderyka Wilhelma III, który w oczach pierwszych mieszkańców wsi był ich dobroczyńcą. Władze pruskie osiedliły tam 60 kolonistów z Pomorza (Heike 1979, s. 22). Zachowany plan Borowej ukazuje wieś liniową, $\mathrm{z}$ budynkami mieszkalnymi usytuowanymi po obu stronach długiej, prosto wytyczonej drogi. Wszystkie chałupy zwrócone były do niej szczytami. Początkowo zamieszkało we wsi 49 chłopów, z których większość gospodarowała na 30-morgowych areałach. $Z$ czasem obszar osady powiększył się w kierunku południowym. Pierwsze lata gospodarowania upłynęły na karczowaniu i uprzątaniu leżących drzew, meliorowaniu podmokłego terenu. Jeszcze 
w 1812 roku miejscowi chłopi przedstawiali się władzom Księstwa Warszawskiego jako „ubodzy koloniści”, prosząc o zwrot kosztów poniesionych na utrzymanie biegnącej przez wieś drogi (AGAD, KRPiS, 850). Wyjaśnić trzeba, że osadnicy z Borowej nie zostali objęci beneficjami rządu pruskiego, ponieważ były one zapewnione jedynie przybyszom z krajów Rzeszy. Między przybyszami z Pomorza osiedlił się $\mathrm{w}$ Borowej jedyny przybysz $\mathrm{z}$ Wirtembergii, J.H. Schmidt, pochodzący z Fuldy, który jako jedyny został objęty wszystkimi przywilejami przewidzianymi dla osadników (Kossmann 1942, s. 195).

Osadnictwo wiejskie, realizowane przez administrację pruską na terenie Prus Południowych, widzieć należy w szerszym kontekście podobnych inicjatyw podejmowanych na przełomie XVIII i XIX wieku przez absolutystyczne monarchie, w których do głosu doszła doktryna kameralizmu. Prusy wyraźnie ustępowały Austrii i Rosji pod względem wielkości powierzchni nowo zasiedlanych terenów. Podczas gdy oba te państwa organizowały na rozległych, bezludnych stepach południowych Węgier i południowej Rosji ogromne wsie, doprowadzając do wytworzenia się w przyszłości lokalnych etnosów (Donauschwaben, Wolgadeutschen, Schwarzemeerdeutschen), to efektem akcji osadniczej w Prusach Południowych było powstanie niewielkich osad zamieszkanych głównie przez małorolnych chłopów, rozrzuconych wśród wsi polskich oraz zasiedlonych przez wcześniej przybyłych osadników niemieckich (Kuhn 1971, s. 193194). Sytuacja taka przyczyniała się do izolacji wsi szwabskich. Poważną i długo utrzymującą się przeszkodą w komunikowaniu się imigrantów z Wirtembergii z otoczeniem, także niemieckim, był dialekt szwabski, którym się posługiwali. Na znaczną odmienność mowy Szwabów zwracał uwagę już w 1801 roku pułkownik von Puhle, nadzorujący osiedlanie się kolonistów w ekonomii Łaznów. Za niezbędne uznał sprowadzenie duchownych i nauczycieli, którzy będą ziomkami kolonistów, gdyż tylko tacy będą się mogli z nimi porozumieć i zyskać ich zaufanie. Zakładane przez administrację pruską kolonie szwabskie, spełniały warunek samowystarczalności, co ograniczało do minimum kontakty ich mieszkańców z otoczeniem. Ćwierć wieku później, obserwując osady Szwabów w ekonomii Sanniki, Julian Ursyn Niemcewicz pisał: „odmienny język, wiara, osobne osady, nie dozwolą nigdy ludowi temu polszczyć się" (Niemcewicz 1858, s. 65). Między sąsiadującymi ze sobą wsiami zamieszkanymi przez Szwabów i przez przybyszów z Pomorza rzadko tylko dochodziło do bliższych kontaktów. Dobitnym dowodem są zawierane w późniejszych latach transakcje kupna-sprzedaży ziemi. Znakomita ich większość zawierana była w obrębie środowiska dawnych krajanów (Woźniak 1995, s. 3-18). Niemal nie spotykało się małżeństw mieszanych, gdyż partnerzy wywodzący się z „obcego" środowiska nie byli tolerowani (Heike 1979, s. 29). Obie grupy, chłopów pomorskich i chłopów ze Szwabii, nie szczędziły sobie nawzajem uszczypliwości i złośliwości, w których Pomorzanie przedstawiani byli jako silni fizycznie, ale niezbyt rzutcy umysłowo, natomiast Szwabowie jako słabi, ale pełni chłopskiej przebiegłości (Heike 1979, s. 29). 
Osadnictwo pruskie na ziemiach polskich niosło ze sobą upowszechnienie gospodarki czynszowej w klasycznej postaci, gdzie poza czynszem pieniężnym i podatkami publicznymi, gospodarze nie byli obciążeni żadnymi innymi świadczeniami. Nie była natomiast nowością planowość w zabudowie wsi. Zalecenia „budowy w linii" spotyka się bardzo często w kontraktach zawieranych z olędrami u schyłku XVIII wieku (APŁ, Not. Stokowski 55/1811; APK, Not. Nowosielski 16/1821; Kossmann 1966, s. 367, 372, 384, 403). Nie ulega jednak wątpliwości, że władze pruskie znacznie bardziej rygorystycznie przestrzegały tej zasady, z czym szło w parze wznoszenie budynków według jednego planu i przez zewnętrznego przedsiębiorcę. Nadawało to koloniom wygląd uporządkowany. Mimo opracowania odpowiednich planów nie udało się jednak administracji pruskiej upowszechnić budownictwa o konstrukcji szachulcowej, znanej i stosowanej przez kolonistów w ich ojczyźnie ${ }^{7}$. Zdarzały się budynki wznoszone tą techniką, jak np. dom podleśnego lasów rządowych Jana Rohra w Nowosolnej, ale ogół chłopów zadowalał się domami wznoszonymi wyłącznie z drewna (AGAD, CWW 1238, s. 20).

Pruska akcja osadnicza miała także istotny cel polityczny. Przy pomocy instrumentów właściwych polityce gospodarczej dążono do umocnienia obecności chłopów niemieckich na ziemiach polskich. W 1804 roku kamera wojenno-ekonomiczna Prus Południowych wydała „Publikandum” skierowane do wszystkich kolonistów w prowincji. Zakazywało ono sprzedaży gospodarstwa przez okres 10 lat po jego nabyciu bez zezwolenia kamery. Zgoda na sprzedaż dotyczyć mogła wyłącznie osadnika przybywającego z zagranicy, a zbywający musiał zadeklarować, na co przeznaczy pieniądze uzyskane ze sprzedaży ziemi. Mogły być one wydatkowane tylko w kraju, tj. na terenie Prus Południowych. Ponadto w ciągu lat wolnych nie wolno było koloniście sprzedawać inwentarza ani zaciągać długu na gospodarstwo bez zezwolenia kamery (Zimmermann 1915, s. 401). Doraźne znaczenie gospodarcze osadnictwa wiejskiego realizowanego przez rząd pruski nie było wielkie. Korzystający z wolnizny koloniści nie wnosili nic do budżetu państwa, natomiast wymagali często dodatkowego wsparcia finansowego. W czterokrotnym wzroście przychodów z tytułu podatków ściąganych z Prus Południowych w latach 1793-1807 nie mieli żadnego udziału. Na dodatni bilans prowincji złożył się przede wszystkim szybki wzrost eksportu zboża oraz niewielki wzrost produkcji sukna (w departamencie poznańskim) (Simsch 1983, s. 254). Zasadniczej przebudowy systemu gospodarczego jednak nie dokonano. Nie udało się ożywić handlu wewnętrznego, zrealizować budowy dróg i rozbudowy miast (Simsch 1983, s. 255). Sprowadzanie kolonistów $\mathrm{z}$ odległych terenów było błędem, na co zwracał już uwagę minister K.G. Hoym. Wielka odległość konieczna do pokonania w podróży podnosiła koszty migracji. Warunki klimatyczne, glebowe, sposób prowadzenia gospo-

\footnotetext{
${ }^{7}$ Zob.: plan budynku szkoły w Hochweiler (Woźniak 2013, s. 362).
} 
darstwa były osadnikom obce, różniły się znacznie od znanych im w stronach ojczystych. Bardzo wysoki był także koszt ich instalacji z powodu konieczności wyposażenia każdego gospodarstwa w inwentarz, narzędzia, materiał siewny. Samo założenie kolonii Grömbach kosztowało rząd pruski 33573 talary 23 grosze (Heike 1979, s. 43). Nie brak też głosów, że działalność administracji pruskiej w Prusach Południowych bardziej przyczyniła się do zahamowania procesu osadniczego niż jego wzmocnienia. Trwający od lat 70. XVIII wieku naturalny, spontaniczny proces osiedlania się na terenach środkowej Polski chłopów z Pomorza i Śląska przerwany został sztuczną i kosztowną migracją z Wirtembergii, która nie przyniosła zamierzonych korzyści (Kiss 1939). Według szacunków ministra O. Vossa, w Prusach Południowych osiedliło się 10293 osadników (APŁ AmZ, 6; Heike 1953, s. 32-34; Kossmann 1978, s. 235). Do tego wyniku przyczyniło się scentralizowane zarządzanie akcją kolonizacyjną, celowy werbunek wśród ochotników i precyzyjnie określony sposób przydziału ziemi. Trwałą pozostałością tego osadnictwa było rozszerzenie gospodarki czynszowej i upowszechnienie regularnej, geometrycznej formy wsi. Zakładano bowiem wyłącznie wsie liniowe, w których główną linię wyznaczała droga wiejska, z przylegającymi do niej, węższymi bokami, poszczególnymi czworokątnymi parcelami działkami osadniczymi. W listopadzie 1806 roku, wraz z wybuchem wojny francusko-pruskiej, akcja kolonizacyjna w Prusach Południowych zakończyła się. Z pruskich doświadczeń skorzystać miały w przyszłości rządy Księstwa Warszawskiego i Królestwa Polskiego.

\section{LITERATURA}

Beer M., 1999, Die „trockene Auswanderung”. Eine thematische und forschungsgeschichtliche Einordnung, [w:] hrsg. von Beer M. und Dahlmann D., Migration nach Ost- und Südosteuropa vom 18. bis zum Beginn des 19. Jahrhunderts, Ursachen -Formen-Verlauf-Ergebnis, Thorbecke, Stuttgart.

Czochański M., Kowalski G., 2014, Geodezja w początkach Królestwa Polskiego. Budowa zbiorów informacji przestrzennej na przykładzie wybranych miast regionu tódzkiego, Wydawnictwo Politechniki Łódzkiej

Effenberger E., 1999, Auf den Spuren unserer Vorfahren, „Information. Mitteilungsblatt der Heimatkreisgemeinschaft der Deutschen aus dem Lodzer Industriegebiet e.V.,,21.

Figlus T., 2014, Wsie olęderskie w Polsce Środkowej. Uwagi na temat zróżnicowania morfogenetycznego na tle rozwoju osadnictwa, ,Rocznik Łódzki”, 61, Łódź.

Gavlitta S., 2009, Zwischen Einladung und Ausweisung. Deutsche bäuerliche Siedler im Königreich Polen 1815-1915, Herder Institut, Marburg.

Górski J., 1985, Z historii myśli ekonomicznej, Studia i materiały, Wydawnictwo Łódzkie, Łódź. 
Heike O., 1953, Die Provinz Südpreußen. Preußische Aufbau- und Verwaltungsarbeit im Warthe- und Weichselgebiet 1793-1806, Johann-Gottfried-Herder Institut, Marburg/ Lahn.

Heike O., 1979, 150 Jahre Schwabensiedlungen in Polen 1795-1945, Selbstverlag, Leverkusen.

Hochgeladen E., 1937, Neusulzfeld. Die Wiege der Brüder in Polen, Libertas, Łódź.

Ihnatowicz I., 1967, Vademecum do badań nad historia XIX $i$ XX wieku, t. 1, Państwowe Wydawnictwo Naukowe, Warszawa.

Karczyńska H., 2009, Osadnictwo braci czeskich i morawskich w zachodniej i środkowej Polsce, [w:] Szczepankiewicz-Battek J. (red.), Geografia historyczna a badania społeczno-gospodarcze, Państwowa Wyższa Szkoła Zawodowa im. Wieltona, LegnicaŁódź.

Kiss E., 1939, Pabianitz. Geschichte des Deutschtums einer mittelpolnischen Stadt und ihrer Umgebung, Historische Gesellschaft für Posen, Posen.

Kossmann E.O., 1938, Neu-Sulzfeld, „Volksfreund-Kalender für Stadt und Land”, 12.

Kossmann E.O., 1942, Die Anfänge des Deutschtums im Litzmannstädter Raum, Verlag von S. Hirzel in Leipzig, Leipzig.

Kossmann O., 1966, Deutsche in Polen. Siedlungsurkunden 16.-19. Jh., Heimatkreisgemeinschaft der Deutschen aus dem Lodzer Industriegebiet, e.V., Viersen.

Kossmann O., 1978, Die Deutschen in Polen seit der Reformation. Historischgeographi-sche Skizzen, J.G. Herder-Institut, Marburg/Lahn.

Kuhn W., 1971, Die preussische Kolonisation unter Friedrich der Grossen, [w:] Deutsche Ostsiedlung in Mittelalter und Neuzeit, hrsg. Von der Kommission zum Studium der deutschen Geschichte im Osten an der Friedrich-Wilhelms-Universität Bonn, Böhlau Verlag, Köln-Wien.

Niemcewicz J.U., 1858, Podróże historyczne po ziemiach polskich między rokiem 1811 a 1828 odbyte, A. Franck, B.M. Wolff, Paryż-Petersburg.

Pytlak A., 1917, Die deutsche Kolonisationsbestrebungen auf den Staatsdomänen im Königreiche Polen von 1793-1864, Verlag Robert Noske, Leipzig.

Schmoller G., 1870, Zur Geschichte der deutschen Kleingewerbe im 19. Jahrhundert, Verlag der Buchhandlung des Waisenhauses, Halle (Saale).

Schmit M., 1942, Mundart und Siedlungsgeschichte der schwäbisch-rheinfränkischen Dörfer bei Litzmannstadt, N.G. Elwert, Marburg.

Schöller H.A., 2009, Neu-Sulzfeld/Nowosolna. 23. Mai 1801-17. Januar 1945. Illustrierte historisch-geographische Erinnerungen an ein Dorf und seine Menschen, Selbsverlag, Erlangen.

Simsch A., 1983, Die Wirtschaftspolitik des preußischen Staates in der Provinz Südpreußen 1793-1806/1807, Duncker \& Humblot, Berlin.

Sokołowski A., 1904, Dzieje porozbiorowe narodu polskiego, t. 1, Wiek, Warszawa.

Steinberg H., 1924, Die Brüder in Polen. Eine Geschichte der Herrnhuter Gemeinschaftsarbeit in Kongreßpolen, Unitätsbuchhandlung, Ganadu.

Szulc E., 1989, Cmentarz ewangelicko-augsburski w Warszawie. Zmarli i ich rodziny, Państwowy Instytut Wydawniczy, Warszawa.

Volker K., 1927, Von den Gründen preussischer Kolonisation auf polnischen Boden 1793-1807, „Deutsche Blätter in Polen”, 4(1), Posen. 
Wąsicki J., 1955, Rozdawnictwo dóbr ziemskich $w$ Prusach Poludniowych $w$ latach 1796-1797, „Przegląd Zachodni”, 11(3/4).

Woźniak K., 1995, Z problemów niemieckiego osadnictwa rolnego w okolicach Łodzi w początkach XIX wieku. Obrót ziemia, „Acta Universitatis Lodziensis”, Folia Historica, 52, Łódź.

Woźniak K.P., 2013, Niemieckie osadnictwo wiejskie między Prosna a Pilica i Wisła od lat 70. XVIII wieku do 1866 roku. Prace i jego interpretacje, Wydawnictwo Uniwersytetu Łódzkiego, Łódź.

Zimmermann K., 1915, Fryderyk Wielki i jego kolonizacja rolna na ziemiach polskich, t. 1-2, Nakładem i czcionkami drukarni i księgarni Św. Wojciecha, Poznań.

\title{
Materiały źródłowe
}

Archiwum Główne Akt Dawnych w Warszawie (AGAD).

Centralne Władze Wyznaniowe (CWW), sygn. 1238, 1240.

Generalne Dyrektorium Departament Prus Południowych (GDDPP), sygn. 488.

Komisja Rządowa Przychodów i Skarbu (KRPiS), sygn. 850.

Rada Stanu i Rada Ministrów Księstwa Warszawskiego (RSiRMKsW), sygn. II 215.

Archiwum Państwowe w Łodzi (APŁ).

Akta miasta Zgierza (AmZ), sygn. 6.

Akta notariusza J. Stokowskiego (Not. Stokowski), nr 55/1811.

Archiwum Państwowe w Kaliszu (APK).

Akta notariusza F. Nowosielskiego, (Not. Nowosielski), nr 16/1821.

Biblioteka Uniwersytetu Warszawskiego, Gabinet Rycin; sygn. Inw. GR 299, 300.

Geheimes Staatsarchiv Preussisches Kulturbesitz w Berlinie, II HA Generaldirektorium, Abt. $10 \mathrm{nr}$ 233, sygn. 142.

Dziennik Urzędowy Województwa Kaliskiego, 1820, nr 28.

Urkunden und Akten zur Geschichte der preußischen Verwaltung in Südpreußen und Neuostpreußen 1793-1806, 1961, hrsg. von I.Ch. Bussenius und W. Hubatsch, Frankfurt-Bonn.

\section{PRUSSIAN LINEAR VILLAGES OF THE LODZ SURROUNDINGS AND THEIR INHABITANTS AT THE BEGINNING OF THE $19^{\text {TH }}$ CENTURY}

\begin{abstract}
Within 1799-1802 Prussian authorities created in the South Prussia province several villages inhabited with peasants brought from Schwaben. All of them were located in woodland and were to be reclaimed by the coming people. There are maps and plans preserved showing five of the villages hence it enabled more detailed description. All the villages, called colonies, had a linear and regular housing scheme. The amount of land given to the particular peasant was determined by his wealth. The area of the biggest farmlands was not bigger than 4 łan $(67 \mathrm{~h})$. Yet the most common were farmlands covering 5-15 h. All of the villages received help from the Prussian administrative
\end{abstract}


offices and were given livestock, tools and seeds. After six years free of any chargé, settlers were obliged to pay rent. The expenses on forming the villages were never reimbursed since the South Prussia became a part of the Duchy of Warsaw and after 1815 a part of Polish Kingdom. The inhabitants preserved their cultural autonomy till 1945y. They were Lutherans and spoke Schwaben dialect difficult to understand even for other German settlers.

Key words: settlement, linear villages, South Prussia, migration, district of Lodz, Germans.

Dr hab. Krzysztof Paweł Woźniak Katedra Historii Polski XIX wieku Wydział Filozoficzno-Historyczny Uniwersytet Łódzki 